\title{
Effect Of Concentration Of Urea (Ammonium Sulfate) Fertilizer On Making Nata De Pina From Pineapple Juice (Ananas Comosus L. Merr)
}

\section{Pengaruh Konsentrasi Pupuk Urea (Ammonium Sulfat) Pada Pembuatan Nata De Pina Dari Sari Buah Nenas (Ananas Comosus L. Merr)}

\author{
Mulawi $^{1)}$, Ayu Kristina ${ }^{2)}$ \\ ${ }^{1)}$ Program Studi Pendidikan Kimia, FKIP Universitas Palangka Raya \\ 2) Program Studi Pendidikan Kimia, FKIP Universitas Palangka Raya \\ Kampus Unpar Tunjung Nyaho, Jl. H. Timang, 73111A \\ Email : unparmulawi@yahoo.com
}

\begin{abstract}
This study aims to explain the effect of the concentration of urea fertilizer (Ammonium Sulfate) on the manufacturing of Nata De Pina. This trial aims to compare different concentrations of urea (Ammonium Sulfate) fertilizer. The parameter observed was the weight of Nata De Pina. This research was conducted in six stages, namely: (1) preparing pineapple, (2) fineness, (3) cooking, (4) cooling, (5) addition of acetobacter xylinum and fermentation, (6) harvesting and measurement of Nata De Pina. Based on the research, it was produced that the way to make Nata De Pina can be done by preparing ripe pineapple fruit and cleaning it and then cutting it into small pieces and mashed using a blender to extract the pineapple juice. When blended, the ratio between pineapple and water is $1 \mathrm{~kg}$ of pineapple with 1 liter of water. Then, filtered to take water or pineapple juice. In addition, other ingredients are also used in the cooking process such as urea fertilizer (Ammonium Sulfate) with different concentrations, sugar, glacial acetic acid, and acetobacter xylinum bacteria. After all the ingredients have been prepared, then do the cooking with a small flame. If it boils, add all the other ingredients except the acetobacter xylinum bacterium and leave it for 2-3 minutes after which the baking sheet is prepared to cool down, when the Nata De Pina solution has cooled down, put in $10 \mathrm{ml}$ of acetobacter xylinum bacteria. After that, the surface of the baking sheet is tightly closed using newspaper and allowed to stand for 14 days for the fermentation process to become a Nata De Pina product. Then the harvesting process of Nata De Pina is carried out and the weight is measured. Nata De Pina with greater weight parameters and good quality is shown in Nata De Pina with the highest concentration of urea (ammonium sulphate) fertilizer, which is 2.5 grams. So in this case, the concentration of urea (Ammonium Sulfate) fertilizer suitable for making Nata De Pina is 2.5 grams.
\end{abstract}

Keywords: Pineapple (Ananas Comosus L. Merr), Urea Fertilizer, Acetobacter Xylinum Bacteria, Nata De Pina

Penelitian ini bertujuan untuk menjelaskan pengaruh konsentrasi Pupuk Urea (Ammonium Sulfat) pada pembuatan Nata De Pina. Uji coba ini bertujuan untuk membandingkan konsentrasi Pupuk Urea (Ammonium Sulfat) yang berbeda-beda. Parameter yang diamati adalah berat Nata De Pina. Penelitian ini dilakukan dengan enam tahap, yaitu : (1) mempersiapkan buah nenas, (2) penghalusan, (3) pemasakan, (4) pendinginan, (5) penambahan bakteri acetobacter xylinum dan fermentasi, (6) panen dan pengukuran Nata De Pina. Berdasarkan penelitian dihasilkan bahwa cara pembuatan Nata De Pina dapat dilakukan dengan menyiapkan buah nenas yang sudah matang dan dibersihkan lalu dipotong kecil-kecil dan dihaluskan menggunakan blender untuk diambil sari nenas nya. Ketika di blender perbandingan antara nenas dan air nya adalah $1 \mathrm{~kg}$ nenas dengan 1 liter air. Kemudian, disaring untuk mengambil air atau sari nenasnya. Selain itu disiapkan juga bahan-bahan lain yang digunakan dalam proses pemasakan seperti Pupuk Urea (Ammonium Sulfat) dengan konsentrasi masing-masing yang berbeda, gula pasir, asam asetat glasial, dan bakteri acetobacter xylinum. Setelah semua bahan sudah disiapkan, Kemudian dilakukan pemasakan dengan nyala api kecil. Jika sudah mendidih, masukan semua bahan yang lain nya kecuali bakteri acetobacter xylinum dan biarkan selama 2-3 menit setelah itu dimasukan keloyang yang telah disiapkan untuk didinginkan, apabila larutan Nata De Pina sudah dingin, di masukan bakteri acetobacter xylinum sebanyak $10 \mathrm{ml}$. Setelah itu, ditutup rapat permukaan loyang dengan menggunakan kertas koran dan didiamkan selama 14 hari untuk dilakukan proses fermentasi agar menjadi produk Nata De Pina. Kemudian dilakukan proses pemanenan Nata De Pina dan di ukur beratnya. Nata De Pina dengan parameter berat yang lebih besar dan memiliki kualitas yang baik ditunjukan pada Nata De Pina dengan konsentrasi Pupuk Urea (Ammonium Sulfat) paling tinggi yaitu 2,5 gram. Sehingga dalam hal ini, konsentrasi Pupuk Urea (Ammonium Sulfat) yang cocok digunakan untuk pembuatan Nata De Pina yaitu sebanyak 2,5 gram.

Kata Kunci: Nenas (Ananas Comosus L. Merr), Pupuk Urea, Bakteri Acetobacter Xylinum, Nata De Pina 


\section{PENDAHULUAN}

Indonesia merupakan salah satu Negara yang mempunyai kekayaan alam berupa potensi buah-buahan yang sangat besar. Hal itu menjadi faktor yang menguntungkan bagi Indonesia untuk mengembangkan sektor sistem agribisnis, yaitu meliputi ketersediaan sumber daya tanah (lahan) yang masih luas dan subur, kesesuaian iklim, potensi tenaga kerja, dan peluang pemasaran produk makin terbuka luas. Tetapi pengolahan berbagai jenis buah-buahan sampai saat ini masih sangat sederhana (tradisional) dan pada umumnya merupakan usaha industri kecil, sehingga rata-rata 86,07 \% dari produksi buah-buahan segar cepat membusuk.

Salah satu jenis buah-buahan yang mempunyai potensi dan bernilai ekonomi yang cukup besar adalah buah nanas, selama ini selain dikonsumsi dalam bentuk segar nenas juga di olah dalam beragam bahan pangan seperti koktil, dikalengkan, manisan, selai, sirup, dan asinan serta jajanan olahan lainnya.

Dalam rangka penganekaragaman hasil olahan nenas maka dikembangkan produk baru yaitu Nata De Pina. Nata De Pina merupakan produk makanan fermentasi yang berasal dari Filipina. Nata merupakan selulosa yang dibentuk oleh bakteri Acetobacter Xylinum berkalori rendah (kadar serat kasar $\pm 2,5 \%$ ) yang memiliki kandungan air $98 \%$. Serat yang ada dalam nata tersebut sangat dibutuhkan dalam proses fisiologis, bahkan dapat membantu para penderita diabetes dan memperlancar pencernaan makanan dalam tubuh. Oleh karena itu produk ini dapat dipakai sebagai sumber makanan berkalori rendah untuk keperluan diet (Astawan dan Astawan 1991).

Kebanyakan industri nata pada saat ini menggunakan bahan baku air kelapa hal ini disebabkan karena air kelapa masih melimpah dan harga nya murah. Walaupun demikian, pengembangan produk Nata De Pina dapat menjadi salah satu pilihan dalam mengembangkan produk nata, karena nenas merupakan komoditi yang mudah diusahakan dana berumur singkat (3-4 tahun) dan memiliki produktivitas yang cukup tinggi (20-80 ton/ha).

Pengembangan produk Nata De Pina mempunyai prospek yang cerah dimasa yang akan datang. Hal ini didasarkan pada kenyataan bahwa semakin banyaknya industri nata yang berdiri dan semakin banyak pula produk mata yang beredar dipasaran. Dalam rangka pengembangan produk nata, maka perlu dicari bahan baku selain air kelapa, salah satu kemungkinannya adalah nenas.

Nanas, nenas, atau ananas (Ananas comosus L. Merr) adalah sejenis tumbuhan tropis yang berasal dari Brazil, Bolivia, dan Paraguay. Tumbuhan ini termasuk dalam familia nanas-nanasan (Famili Bromeliaceae). Perawakan (habitus) tumbuhannya rendah, herba (menahun) dengan 30 atau lebih daun yang panjang, berujung tajam, tersusun dalam bentuk roset mengelilingi batang yang tebal.

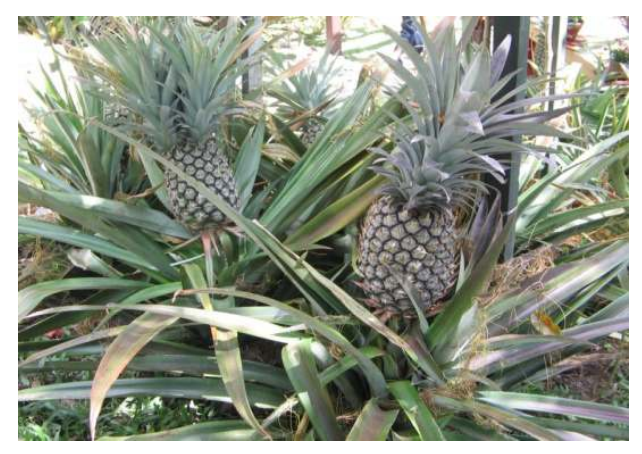

Buahnya dalam bahasa inggris disebut pineapple karena bentuknya yang seperti pohon pinus. Nama "Nanas" berasal dari sebutan orang Tupi untuk buah ini : anana, yang bermakna "buah yang sangat baik".

Nanas termasuk kedalam divisi Plantae, sub divisi Spermatophyta, kelas Monocotyledonae, ordo Farinosae, famili Bromeliaceae, genus Ananas, spesies Ananas Comosus (Collins,1960).

Menurut Wijandi (1988), ada beberapa macam jenis nanas, yaitu :

1. Cayenne

Nenas ini matanya tidak berduri, buahnya berwarna hijau kekuningan dan rasanya agak asam. Jenis ini baik untuk dikalengkan karena mempunyai serat yang kasar, sehingga tidak mudah hancur. Berat buah ini berkisar $0,75-1,5 \mathrm{~kg}$.

2. Spanish a. Red Spanish

Jenis ini tahan terhadap penyakit dan berumur panjang, berat buah berkisar 0,9-1,8 kg, daging buah berwarna putih, kulit buah kuat dan kompak sehingga cocok dikirim ketempat yang jauh dengan pengapalan dalam bentuk segar.

b. Singapore Spanish

Berat buah berkisar 1,6-2,3 kg kulit buah yang masak berwarna merah orange dan daging buah berwarna kuning, berserat banyak dan mempunyai flavor yang baik, sehingga cocok untuk dikalengkan.

3. Queen

Daging buah berwarna kuning, berat buah berkisar 1-1,5 $\mathrm{kg}$, rasanya manis dan flavornya baik sehingga cocok untuk dimakan segar. Di Indonesia jenis ini banyak ditanam didaerah Kediri dan Blitar. Pada umumnya 
buah nenas dapat dibagi menjadi tiga bagian yaitu kulit, daging, dan hati. Komposisi kimia buah nenas

dapat dilihat pada Tabel 1 berikut ini.

Tabel 1. Komposisi kimia buah nenas segar

\begin{tabular}{|c|c|}
\hline Komponen & Jumlah \\
\hline Total padatan terlarut (oBrix) & $10,8-17,5$ \\
Abu (\%) & $0,3-0,4$ \\
Air (\%) & $81,2-86,5$ \\
Serat (\%) & $0,30-0,61$ \\
Nitrogen (\%) & $0,045-0,115$ \\
Eter (\%) & 0,2 \\
Ester (ppm) & $1,0-250$ \\
\hline
\end{tabular}

Menurut Dull (1971), asam organik utama yang terdapat dalam buah nenas adalah asam sitrat dan merupakan asam-asam non volatile yang terbanyak dalam buah nenas. Selain asam sitrat, dalam buah nenas juga terdapat asam malat dan oksalat (Tabel 2). Selain mengandung asam, buah nenas juga mengandung karbohidrat seperti yang terlihat pada Tabel 3.

Tabel 2. Komposisi asam buah nenas segar

\begin{tabular}{|c|c|}
\hline Asam Organik & Jumlah (\%) \\
\hline Asam sitrat & $0,30-1,22$ \\
Asam malat & $0,10-1,22$ \\
Asam oksalat & 0,005 \\
Total asam tertitrasi & $0,62-1,62$ \\
\hline
\end{tabular}

Tabel 3. Komposisi karbohidrat buah nenas segar

\begin{tabular}{|c|c|}
\hline Karbohidrat & Jumlah (\%) \\
\hline Glukosa & $1,00-3,20$ \\
Fruktosa & $0,60-2,30$ \\
Sukrosa & $5,90-12,0$ \\
Pati & 0,002 \\
Selulosa & $0,43-0,54$ \\
Heksosa & $0,10-0,15$ \\
Pentosa & $0,33-0,43$ \\
Pektin & $0,06-0,16$ \\
\hline
\end{tabular}

Komposisi sari buah nenas segar terdiri dari zat padat $(16,43 \%)$, asam sitrat $(0,615 \%)$, gula invert $(3,6 \%)$, dan sukrosa $(8,87 \%)$, nilai ini merupakan nilai rata-rata. Lebih lanjut dikatakan bahwa asam sitrat adalah asam bebas yang terdapat dalam buah nenas dengan persentase relative rendah (Muljohardjo, 1984).

\section{A. Bakteri Pembentuk Nata}

1. Sifat Bakteri Nata

Menurut Lapuz et al. (1967), bakteri pertama-tama yang diduga sebagai pembentuk nata adalah Leunconostoc sp. Tetapi kemudian diketahui bahwa bakteri yang membentuk nata adalah Acetobacter Xylinum. Bakteri Acetobacter Xylinum termasuk golongan Acetobacter yang mempunyai ciri-ciri antara lain gram negatif, obligat aerobik, berbentuk batang, membentuk kapsul, bersifat non motil dan tidak membentuk spora. Spesies yang telah dikenal antara lain $A$. aceti, $A$. orleanensis, A. liquefaciens, A. Xylinum. Meskipun mempunyai ciri-ciri yang hamper sama dengan spesies lain, namun apabila acetobacter xylinum ditumbuhkan pada media yang mengandung gula, maka bakteri ini akan memecah gula untuk mensintesa suatu polisakarida yang dikenal dengan selulosa ekstraseluler (Laskin dan Lecheiver, 1977).

Acetobacter xylinum mempunyai sifat sensitif terhadap perubahan dari sifat fisik dan kimia lingkungannya, dan ini akan berpengaruh terhadap nata yang dihasilkan (Lapuz et al. , 1967). Beberapa Acetobacter, terutama Acetobacter xylinum mempunyai aktivitas oksidasi lanjutan yang sangat lambat, mengubah asam asetat menjadi $\mathrm{CO}_{2}$ dan $\mathrm{H}_{2} \mathrm{O}$ secara aerobik melalui lintasan asam trikarboksilat (Carr dan Passmore, 1074).

\section{Pertumbuhan pada media cair}

Menurut Lapuz et al. (1967), tanda awal pertumbuhan bakteri nata pada media cair yang 
mengandung gula berupa timbulnya kekeruhan setelah 24 jam inkubasi pada suhu kamar. Setelah $36-48$ jam, suatu lapisan tembus cahaya mulai terbentuk dipermukaan media dan secara bertahap akan menebal membentuk lapisan yang kompak. Jika diganggu, lapisan ini akan tenggelam dan lapisan baru akan terbentuk dipermukaan selama kondisinya masih memungkinkan. Dibawah kondisi yang mendukung, nata yang terbentuk dapat mencapai tebal lebih dari lima $\mathrm{cm}$ dalam waktu satu bulan.

Valla dan Kjosbakken (1981) melaporkan bahwa pertumbuhan sel bakteri Acetobacter Xylinum pada kultur cair yang digoyang telah mencapai maksimum pada jam ke -48 , sementara pada kultur yang didiamkan jumlah maksimumnya baru tercapai setelah disimpan selama 3-4 hari. Dalam pertumbuhannya, sel bakteri Acetobacter Xylinum akan segera berkembang pesat dari jumlah sel awal yang rendah meningkat secara eksponensial sampai tercapai jumlah yang maksimum dengan waktu generasi kira-kira 2 jam. Ketika jumlah sel kira-kira $10^{7}$ sel per $\mathrm{ml}$ kultur, agregat mulai tampak terbentuk dan jumlah sel di dalam larutan tidak meningkat lebih lanjut. Hal tersebut diduga disebabkan selama pembentukan agregat sebagian sel Acetobacter Xylinum masuk diantara ronggarongga dalam agregat, sehingga tidak bebas lagi didalam larutan. Menurut Valla dan Kjosbakken (1981), pembentukan agregat dapat memperpanjang waktu generasi.

\section{Aktivitas Pembentukan Nata}

Menurut Valla dan Kjosbakken (1981); Thimann dan Kenneth (1955), bakteri Acetobacter Xylinum mempunyai aktivitas dapat memecah gula untuk mensintesa selulosa ekstraseluler. Selulosa yang terbentuk berupa benang-benang yang bersama-sama dengan polisakarida berlendir membentuk suatu jalinan yang terus menebal menjadi lapisan nata. Dari penelitian dengan menggunakan sinar $\mathrm{X}$ diketahui bahwa pola selulosa yang dibentuk oleh bakteri Acetobacter Xylinum identik dengan struktur selulosa kapas.

Aktivitas pembentukan nata hanya terjadi pada kisaran $\mathrm{pH}$ antara 3,5 - 7,5. Kualitas nata terbaik dan terbanyak tercapai pada $\mathrm{pH} \mathrm{5,0}$ dan 5,5 dalam media air kelapa dan pada suhu kamar (Lapuz, et al.,1967). Sedangkan menurut Widia (1984), kualitas dan jumlah nata terbanyak dihasilkan pada media air kelapa mempunyai $\mathrm{pH} 4,5$. Menurut Herman (1979) kondisi $\mathrm{pH}$ optimum untuk pembentukan nata terjadi pada $\mathrm{pH} 4,0$ pada media air kelapa.

Terbentuknya pelikel (lapisan tipis nata) mulai dapat dilihat dipermukaan media cair setelah 24 jam inkubasi, bersamaan dengan terjadinya proses penjernihan cairan dibawahnya. Jaringan halus yang transparan yang terbentuk dipermukaan membawa sebagian bakterik yang terperangkap didalamnya. Gas karbondioksida yang dihasilkan secara lambat oleh Acetobacter Xylinum mungkin menyebabkan pengapungan nata, sehingga nata, terdorong kepermukaan (Schramm dan Hestrin, 1954 di dalam Colvin, et al.,1977).

Menurut Whistler et al. (1976), polisakarida bakteri yang dibentuk oleh enzim-enzim Acetobacter Xylinum berasal dari suatu prekursor yang berikatan $\beta$ (1-4) yang tersusun dari komponen gula yaitu glukosa, manosa, ribose dan rhamnosa. Prekursor dalam pembentukan selulosa oleh Acetobacter Xylinum ialah UDPG (Urasil Difosfoglukosa). Mekanisme pembentukan selulosa oleh Acetobacter Xylinum terlihat pada gambar 1 berikut ini.

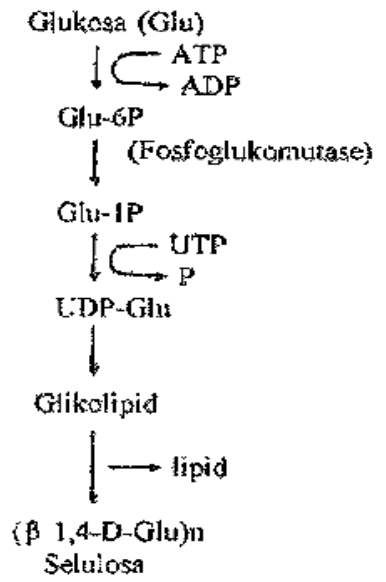

Gambar 1. Mekanisme pembentukan selulosa oleh Acetobacter Xylinum (Hassid, 1970)

Peningkatan jumlah selulosa yang relative cepat diduga terjadi akibat konsentrasi sel yang terus berkembang didaerah permukaan yang langsung kontak dengan udara didalam wadah fermentasi. Pada kultur yang tumbuh, suplai oksigen dipermukaan akan merangsang peningkatan massa sel dan enzim pembentuk selulosa, akibatnya akan meningkatkan produksi selulosa (Schramm dan Hestrin, 1954 di dalam Colvin, et al., 1977).

Gel selulosa tidak terbentuk jika didalam media tidak tersedia glukosa atau oksigen, tidak terdapatnya glukosa menyebabkan laju konsumsi oksigen menjadi tidak berarti, yaitu kurang dari 0,01 mikromol per sel per 
jam. Dan dengan adanya glukosa, maka laju konsumsi oksigen akan meningkat sampai kira-kira 4 mikromol per sel per jam (Hestrin dan Schramm, 1954).

\section{B. Produksi Nata}

Menurut Herman et al. (1975), proses pembuatan nata pada dasarnya meliputi enam tahap kegiatan, yaitu penyiapan substrat, penyiapan media, penyiapan starter, pemeraman, pengilangan asam, dan tahap pemasakan. Pemberian nama produk disesuaikan dengan bahan media, seperti nata de coco untuk produk dari air kelapa dan Nata De Pina untuk produk dari nenas. Pertumbuhan Acetobacter Xylinum dipengaruhi oleh faktor-faktor antara lain $\mathrm{pH}$, suhu, sumber nitrogen, dan sumber karbon ( Lapuz et al. 1967).

Menurut Herman (1979) sebagai sumber karbon dapat digunakan berbagai jenis gula seperti glukosa, sukrosa, fruktosa, ataupun maltosa dan untuk mengatur $\mathrm{pH}$ digunakan asam asetat glasial. Menurut Sulistyo (1992), penambahan sukrosa 7,5 \% dalam fermentasi Nata De Pina menghasilkan rendemen tertinggi 42,8\%.

Tingkat konsentrasi Ammonium Sulfat yang ditambahkan pada media untuk pembuatan nata de coco mempengaruhi rendemen nata yang dihasilkan. Pada penambahan Ammonium Sulfat 0,5 \% menghasilkan rendemen tertinggi (70,64\%) (Mashudi, 1993).

Faktor lain yang berpengaruh terhadap hasil nata adalah wadah fermentasi. Untuk efisiensi dan efektivitas hasil nata serta mempertinggi rendemen lebih baik digunakan wadah yang berbentuk segi empat dan luas permukaan yang relatif besar. Hal ini disebabkan karena pada kondisi yang demikian ini pertukaran oksigen dapat berlangsung dengan baik (Rosario, 1982).

\section{Amonium Sulfat}

Amonium sulfat merupakan senyawa kimia dengan rumus kimia $\left(\mathrm{NH}_{4}\right)_{2} \mathrm{SO}_{4}$ yang berbentuk Kristal, berwarna abu-abu, kebiru-biruan, atau kuning, tetapi paling banyak berwarna putih seperti gula pasir. Senyawa ini mengandung nitrogen antara 20,4\% - 21\%, tidak bersifat higroskopis dan baru akan menyerap air bila kelembaban nisbi sudah mencapai $80 \%$ pada suhu $30 \% \mathrm{C}$ (Hardjowigeno, 1987).

Menurut Considene (1982), Ammonium Sulfat dapat dihasilkan melalui dua proses, yaitu pertama mereaksikan amonia dengan asam sulfat, seperti yang terlihat pada persamaan reaksi berikut ini :

$$
2 \mathrm{NH}_{3}+\mathrm{H}_{2} \mathrm{SO}_{4} \rightarrow\left(\mathrm{NH}_{4}\right)_{2} \mathrm{SO}_{4}
$$

Sedangkan proses kedua dengan mereaksikan ammonium karbonat dengan kalium sulfat seperti yang terlihat pada persamaan reaksi berikut ini :

$$
\left(\mathrm{NH}_{4}\right)_{2} \mathrm{CO}_{3}+\mathrm{CaSO}_{4} \rightarrow\left(\mathrm{NH}_{4}\right)_{2} \mathrm{SO}_{4}+\mathrm{H}_{2} \mathrm{O}
$$

Amonium sulfat dapat digunakan sebagai sumber nitrogen untuk membantu pertumbuhan Acetobacter pada pembuatan vinegar dan nata de coco (Steinkraus, 1982).

\section{Sukrosa}

Sukrosa adalah oligosakarida (disakarida) yang mempunyai peran penting dalam pengolahan makanan dan banyak terdapat pada tebu, bit, dan siwalan dan kelapa kopyor. Untuk industri-industri makanan biasa digunakan sukrosa dalam bentuk Kristal halus atau kasar dan dalam jumlah yang banyak dipergunakan dalam bentuk cairan sukrosa (sirup). Pada pembuatan sirup, gula pasir (sukrosa) dilarutkan dalam air dan dipanaskan, sebagian sukrosa akan terurai menjadi glukosa dan fruktosa, yang disebut gula invert. Inversi gula terjadi dalam suasana asam (Winarno, 1984).

Sukrosa dapat terhidrolisa dengan adanya ion hidrogen atau enzim tertentu menjadi D-Glukosa dan DFruktosa, sedangkan dengan adanya ion hidroksil dan pemanasan akan terjadi dekomposisi serta terbentuk furfural, 5-hidroksil-metil-2 furfural, metal glioksil, gliseraldehida, dioksiaseton, aseton, asam laktat, asam trioksiglutarat, asam trioksibutirat, asam asetat, asam format dan $\mathrm{CO}_{2}$ (Goutara dan Wijandi, 1975).

Gula dapat terdekomposisi oleh bakteri dan khamir. Aktivitas mikroba dalam substrat yang mengandung gula dapat bermacam-macam tergantung jenis dan sifat mikroba yang bersangkutan.

\section{METODE PENELITIAN}

\section{A. Alat dan Bahan}

Alat yang digunakan untuk membuat Nata De Pina antara lain pisau stailess steel, timbangan berkapasitas 2 $\mathrm{kg}$, baskom, loyang plastik persegi panjang, gelas ukur, saringan plastik, neraca ohaus, kompor, panci, sendok, sedotan (sebagai pengganti pipet), dan koran. Bahanbahan yang digunakan untuk membuat Nata De Pina adalah buah nenas yang sudah matang, gula pasir (sukrosa), asam asetat glasial, Pupuk Urea (Ammonium Sulfat), bakteri acetobacter xylinum dan air bersih.

\section{B. Tempat Penelitian}

Penelitian ini dilakukan di rumah yang beralamat di jalan Bukit Keminting $\mathrm{X}$ gang Bima $\mathrm{V}$, Kecamatan Jekan Raya, Palangka Raya.

\section{Eksperimen Penelitian}

Penelitian ini merupakan penelitian yang dilakukan dengan metode eksperimen, dimana data-data yang diperoleh melalui serangkaian percobaan.

\section{Prosedur Kerja}

Pada prosedur kerja pembuatan Nata De Pina ini dilakukan dengan menggunakan 5 jenis konsentrasi Pupuk Urea yang berbeda-beda sehingga di lakukan pada 5 loyang yang berbeda pula. Adapun prosedur kerja yang dilakukan untuk membuat Nata De Pina antara lain.

1. Mempersiapkan buah nenas

Disiapkan buah nenas yang berkualitas baik dan dalam keadaan matang dan selanjutkan di lakukan pengupasan untuk diambil daging buah nenas tersebut kemudia di potong menjadi beberapa bagian dengan 
ukuran yang kecil agar mempermudah pada proses penghancuran.

2. Penghalusan

Buah nenas yang sudah di potong pada prosedur kerja yang pertama selanjutnya akan di haluskan menggunakan blender dengan perbandingan daging nenas dengan air yaitu $1: 1 / 4$, setelah daging buah nenas hancur selanjutnya dilakukan penyaringan untuk memisahkan air atau sari dengan ampas dari daging buah nenas tersebut.

3. Pemasakan

Sari buah nenas yang telah di peroleh selanjutkan akan di masak. Sebelum memasak sari buah nenas tersebut terlebih dahulu disiapkan bahan-bahan kimia dan bahan lain nya yang telah di ukur banyak nya seperti gula pasir ( 100 gr) , Pupuk Urea (2,5 gr, 2 gr, 1,5 gr, 1 gr, dan $0,5 \mathrm{gr})$, asam asetat glasial $(10 \mathrm{ml})$, serta bakteri acetobacter xylinum ( $10 \mathrm{ml}$ ). Setelah semua bahan sudah siap maka sari buah nenas akan dimasak hingga mendidih, ketika sudah mendidih masukan satu persatu bahan. Yang pertama dimasukan terlebih dahulu gula pasir, lalu Pupuk Urea dan yang terakhir asam asetat glasial di aduk hingga semua bahan larut dan homogen jika sudah matikan kompor.

4. Pendinginan

Disiapkan loyang plastik berbentuk persegi dalam keadaan bersih dan kering. Selanjutnya, dituangkan sari buah nenas yang telah dimasak secara perlahan ke dalam loyang, lalu biarkan sampai dingin dengan menggunakan suhu ruangan.
5. Penambahan bakteri acetobacter xylinum dan fermentasi

Apabila sari buah nenas yang terdapat di loyang sudah dalam keadaan dingin, selanjutnya akan ditambahkan bakteri acetobacter xylinum sebanyak $10 \mathrm{ml}$ dan tidak perlu di aduk. Kemudian tutup rapat permukaan loyang dengan menggunakan koran dan di berikan perekat pada sisi samping loyang agar Koran dapat menutup loyang dengan baik. Selanjutnya simpan loyang di tempat yang kering dan tidak mudah tergoyang ataupun terjatuh dan dilakukan fermentasi selama 14 hari.

6. Panen dan pengukuran Nata De Pina

Setelah dilakukan fermentasi selama 14 hari lama nya kan muncul lapisan kenyal dan padat pada permukaan, Kemudian dibersihkan dengan menggunakan air bersih dan selanjutnya akan di ukur berat bersih dari Nata De Pina dengan menggunakan timbangan. Setelah selesai dilakukan pengukuran Nata De Pina dimasukan ke loyang yang sudah bersih kemudian di rendam dengan menggunakan air bersih dan di lanjutkan pengukuran pada hari berikut nya sampai tidak terjadi penambahan berat pada Nata De Pina.

\section{HASIL PENGAMATAN DAN PEMBAHASAN}

\section{A. Hasil Pengamatan}

Pengaruh konsentrasi Pupuk Urea terhadap pembuatan Nata De Pina ditunjukan pada Tabel 4 berikut.

Tabel 4. Pengaruh Konsentrasi Pupuk Urea terhadap Pembuatan Nata De Pina

\begin{tabular}{|c|c|c|c|c|c|}
\hline \multirow{2}{*}{$\begin{array}{c}\text { Penimbang hari } \\
\text { ke }\end{array}$} & \multicolumn{5}{|c|}{ Konsentrasi Urea } \\
\cline { 2 - 6 } & $\mathbf{2 , 5}$ gram & $\mathbf{2}$ gram & $\mathbf{1 , 5}$ gram & $\mathbf{1}$ gram & $\mathbf{0 , 5}$ gram \\
\hline 1 & 150 gram & 125 gram & 120 gram & 50 gram & 20 gram \\
\hline 2 & 200 gram & 175 gram & 125 gram & 75 gram & 25 gram \\
\hline 3 & 225 gram & 200 gram & 150 gram & 100 gram & 50 gram \\
\hline 4 & 250 gram & 225 gram & 175 gram & 125 gram & 75 gram \\
\hline
\end{tabular}

Tabel 4 Memberikan informasi tentang pengaruh konsentrasi Pupuk Urea terhadap pembuatan Nata De Pina. Informasi perbandingan berat Nata De Pina menggunakan Pupuk Urea dapat dilihat dari grafik pada gambar 2 berikut.

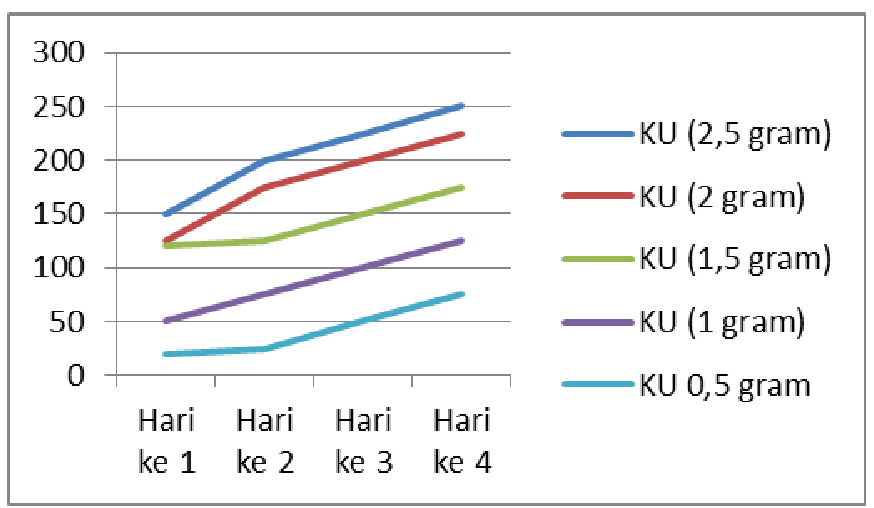

Gambar 2. Perbandingan Konsentrasi Pupuk Urea terhadap Berat Nata De Pina 


\section{B. Pembahasan}

Berdasarkan Tabel 1 telah dilakukan pengamatan terhadap 5 Nata De Pina dengan memberikan perlakuan konsentrasi Ammonium Sulfat (Pupuk Urea) yang berbeda. Pemberian konsentrasi
Ammonium Sulfat (Pupuk Urea) yang berbeda pada setiap Nata De Pina menyebabkan perbedaan berat, ketebalan serta warna yang dihasilkan. Pada ke 5 Nata De Pina diberikan konsentrasi yang berbeda, yang dijelaskan melalui Tabel 2.

Tabel 2. Konsentrasi Pupuk Urea (Ammonium Sulfat) yang digunakan pada setiap wadah

\begin{tabular}{|c|c|}
\hline Wadah & $\begin{array}{c}\text { Konsentrasi Pupuk Urea } \\
\text { (Ammonium Sulfat) }\end{array}$ \\
\hline 1 & 2,5 gram \\
\hline 2 & 2 gram \\
\hline 3 & 1,5 gram \\
\hline 4 & 1 gram \\
\hline 5 & 0,5 gram \\
\hline
\end{tabular}

Selain Pupuk Urea (Ammonium Sulfat), adapun bahan-bahan yang lain yang digunakan dalam penelitian ini yaitu Bakteri acetobacter xylinum sebanyak $10 \mathrm{ml}$, Asam asetat glasial $10 \mathrm{ml}$, Gula 100 gram, dan nenas $1 \mathrm{~kg}$ (sari nenas nya) pada tiap wadah.

Produk Nata De Pina yang di hasilkan memiliki warna putih jernih dan berbau asam namun ada pula satu wadah yang menghasilkan Nata De Pina dengan warna yang agak gelap yaitu pada wadah Nata De Pina dengan konsentrasi Pupuk Urea sebanyak 1,5 gram. Hal ini disebabkan karena pada saat proses pemasakan dibiarkan terlalu lama seharusnya setelah sedikit mendidih langsung diangkat kemudian dituangkan kewadah dan di biarkan dingin lalu di tuangkan bakteri acetobacter xylinum. Acetobacter xylinum tidak boleh dituangkan pada saat larutan Nata De Pina masih panas, hal ini dapat menyebabkan bakteri nya mati dan tidak berfungsi dengan baik pada saat fementasi. Fermentasi Nata De Pina dilakukan selama 14 hari pada tempat yang kering dan bersih serta jauh dari goncangan yang dapat mengganggu fermentasi Nata De Pina.

Nata De Pina yang sudah difermentasikan selama 14 hari, di timbang berat nya setiap hari dengan menggunakan timbangan hingga tidak ada lagi penambahan berat. Penimbangan yang dilakukan berlangsung selama 4 hari, dimana setiap hari setelah melakukan penimbangan, air rendaman Nata De Pina sebelum nya diganti dengan air yang baru. Pada setiap kali melakukan penimbangan dari hari ke 1 sampai hari ke 4, rata-rata berat Nata De Pina mengalami peningkatan atau penambahan sebanyak $25 \%$. Penimbangan hanya dilakukan selama 4 hari karena Nata De Pina sudah tidak mengalami peningkatan atau penambahan berat pada saat dilakukan penimbangan pada hari ke 5 .

Pada wadah yang diberikan konsentrasi Pupuk Urea lebih banyak yaitu pada 2,5 gram, 2 gram, dan 1,5 gram cenderung menghasilkan berat dan ketebalan yang lebih besar pada produk Nata De Pina sedangkan pada wadah yang diberikan konsentrasi Pupuk Urea yang lebih sedikit yaitu pada 1 gram dan 0,5 gram cenderung menghasilkan berat dan ketebalan yang lebih kecil.

\section{Kesimpulan dan Saran}

\section{A. Kesimpulan}

Berdasarkan hasil penelitian ini dapat disimpulkan bahwa untuk melihat pengaruh besar kecil konsentrasi Pupuk Urea (Ammonium Sulfat) pada pembuatan Nata De Pina. Pada Nata De Pina yang memiliki kadar konsentrasi Pupuk Urea (Ammonium Sulfat) tinggi cenderung memiliki mutu yang baik seperti ketebalan, kekenyalan dan berat yang lebih besar dibandingkan Nata De Pina yang memiliki kadar konsentrasi urea lebih rendah. Sehingga pada hal ini Pupuk Urea (Ammonium Sulfat) memiliki pengaruh yang besar terhadap produk Nata De Pina. Semakin banyak kadar Pupuk Urea (Ammonium Sulfat) pada pembuatan Nata De Pina maka semakin baik mutu dan kualitas Nata De Pina tersebut.

B. Saran

Berdasarkan hasil penelitian, maka penulis mengajukan beberapa saran sebagai berikut :

1. Untuk penelitian selanjutnya diharapkan lebih memperhatikan waktu yang digunakan pada proses pemasakan Nata De Pina. Agar tidak menggunakan waktu yang berlebihan atau cukup lama sehingga dapat menghasilkan produk Nata De Pina yang bermutu kurang baik.

2. Untuk penelitian selanjutnya juga perlu disiapkan alat yang lebih mendukung untuk melakukan pengukuran bahan yang akan digunakan dalam pembuatan Nata De Pina.

3. Untuk penelitian selanjutnya di harapkan bahan yang digunakan untuk pembuatan Nata De Pina semua nya berasal dari bahan alam.

4. Bagi konsumen Nata De Pina haruslah berhati-hati dalam memilih produk Nata De Pina. Pastikan kadar zat kimia yang digunakan masih dalam ambang batas aman untuk di konsumsi.

\section{DAFTAR PUSTAKA}

[1]. Carr dan Passmore. 1974. Methode for identifying acetic acid bacteria. Research Station. University of Bristol 
[2]. Dull. 1971. The Pineapple: General. Di dalam Hulmer, A.C. (ed). The Biochemistry of Fruit and Their Products. New York: Academic Press

[3]. Eribowo Arsatmojo. 1996. Formulasi Pembuatan Nata De Pina. Bogor: IPB

[4]. Herman dkk. 1975. Pengolahan kelapa fermentasi air kelapa menjadi nata de coco. Bogor: Teknologi Pangan III
[5]. Lapuz dkk. 1967. The nata organism-cultural requirements, characteristics and identify. Philippine $\mathrm{J}$ of Sci Laskin. 1977. Handbook of Microbiology.Florida: CRC Press

[6]. Muljohardjo. 1984. Nenas dan Teknologi Pengolahannya. Yogyakarta: Liberty 